\title{
Adoption of environmentally-friendly agricultural technologies amongst smallholder farmers: The case of rocket barns technology in flue-cured tobacco curing in Uganda
}

\author{
Henry Omara ${ }^{1}$, Walter Odongo ${ }^{1}$, and Enos Kule ${ }^{1}$ \\ ${ }^{1}$ Gulu University
}

May 26, 2020

\begin{abstract}
Tobacco production and curing is the single most important contributor to soil degradation and deforestation. To minimise the environmental effects of tobacco production, the environmentally friendly, and energy-efficient rocket barns technology was developed. In spite of its energy saving and environmental benefits, the adoption of rocket barns remains low and understudied. This paper assessed farmers perception and factors affecting the adoption of rocket barn technology. Data was collected using in a cross-sectional survey using structured questionnaires were from 242 Flue Cured Virginia (FCV) tobacco farmers in Uganda. Analysed was done using SPSS and STATA software. Results show that the adoption of rocket barn technology was low, at $12 \%$, with farmers. Farmers perceived adopting the rocket barns technology to be risky and costly. Experience, training, distance to wood fuel, access to extension information, and benefits and risk perceptions were the major determinants of adoption of rocket barns technology. Promotion and adoption of rocket barns technology will require concerted sensitization and training of farmers on the environmental benefits of rocket barn technology. Emphasis such efforts should target the relatively young and inexperienced FCV tobacco farmers.
\end{abstract}

\section{Hosted file}

Manuscript.docx available at https://authorea.com/users/326493/articles/454343-adoption-ofenvironmentally-friendly-agricultural-technologies-amongst-smallholder-farmers-the-caseof-rocket-barns-technology-in-flue-cured-tobacco-curing-in-uganda 